\title{
Agricultural

\section{Effect of sodium benzoate on the shelf life of vacuum packed Catla fish steaks stored at chilled temperature}

Kedar, J. G., Pagarkar, A. U*, Shingare, P. E., Bhosale, B. P., Shinde, K. M. and Kulkarni, G. N. College of Fisheries, (Dr. B. S. Konkan Agricultural University, Dapoli) Shirgaon, Ratnagiri- 415629, Maharashtra, India

\section{ABSTRACT}

Fish is a rich source of high quality protein, essential vitamins and polyunsaturated fatty acids. The increasing demand for high quality fresh seafood has intensified the search for methods and technologies for better fish utilization. Modified atmosphere packaging (MAP) and vacuum packaging (VP), along with refrigeration, have become increasingly popular preservation techniques, which have brought major changes in storage, distribution, and marketing of raw and processed products to meet consumer demands. In the present study, organoleptic, biochemical and microbiological quality changes were observed in chilled stored vacuum packed catla fish steaks treated with 0.0, 0.5, 1.0, 1.5 and 2.0\% sodium benzoate. Organoleptic, biochemical and microbiological analysis showed that chilled stored vacuum packed catla fish steaks with treatment of sodium benzoate had longer shelf life of 27 days, whereas untreated vacuum packed catla fish steaks had a shelf life of 18 days. The results of present study revealed that vacuum packaging alone, without treatment, would not be of much effective under the reported experimental conditions. The findings of the present study, clearly suggest that a combination of vacuum packaging, sodium benzoate and storage at chilled temperature could be used to prolong the shelf life of catla.

\section{KEY WORDS: VACUUM PACKAGING, SODIUM BENZOATE, CHILLED STORAGE, SHELF LIFE, CATLA FISH}

\section{INTRODUCTION}

Fish is a rich source of high quality protein, essential vitamins and polyunsaturated fatty acids (Mohan et al., 2009). The increasing demand for high quality fresh seafood has intensified the search for methods and technologies for better fish utilization. Modified atmosphere packaging (MAP) and vacuum packaging (VP), along

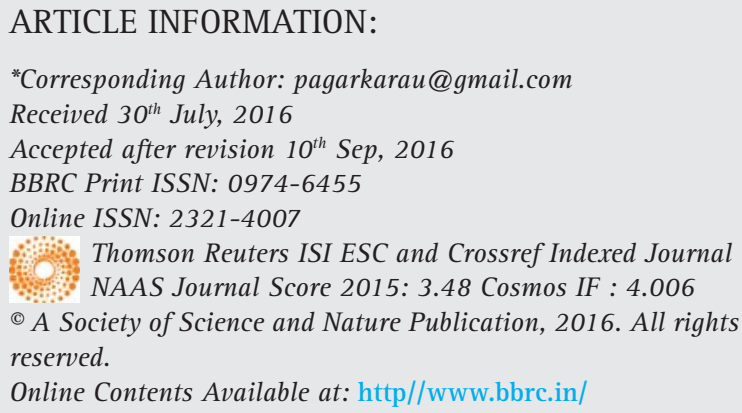

with refrigeration, have become increasingly popular preservation techniques, which have brought major changes in storage, distribution, and marketing of raw and processed products to meet consumer demands (Ozogul et al., 2004; Pagarkar et al., 2015 ).

Sodium benzoate $\left(\mathrm{NaC}_{6} \mathrm{H}_{5} \mathrm{CO}_{2}\right)$ is a preservative found naturally in cranberries, prunes, greengage plums, cinnamon, cloves and apples. The Food and Drug Admin- 
istration (FDA) includes sodium benzoate in its list of direct food substances affirmed as Generally Recognized As Safe (GRAS). Sodium benzoate has been generally reported to be used at concentrations below 0.1\% (CFR, 2011). In some countries levels up to $0.2 \%$ and $0.3 \%$ are permitted and are commonly used (Sara et al., 1994). Sodium benzoate has antimicrobial properties preventing the growth of bacteria and mold. It prolongs the shelf life of fish for a very long period without affecting its texture, taste and appearance (Omojowo, et al., 2010). Catla (Catla catla) is one of the fastest growing fresh water fish among the Indian major carps and it is cultured throughout India on large scale. It is marketed in fresh or iced conditions in the domestic areas. Preparation of chilled steaks of catla in 'ready-to-cook' form would enable to market the fish to long distanc.

\section{MATERIAL AND METHODS}

Freshly caught catla (Catla catla) fish samples procured from Tasgaon reservoir at Sangli district in western Maharashtra (India) were immediately brought to the laboratory in iced condition by keeping in insulted boxes filled with crushed ice in the ratio of 1:1 for further processing. Steaks of thickness $1.5-2.0 \mathrm{~cm}$ were made following the method of Shalima (1997). The steaks were divided into 5 groups and were dipped in solution of sodium benzoate of $0.0,0.5,1.0,1.5$ and 2.0\% concentration respectively, for 5 minute. After proper draining vacuum packaging was carried out in packaging material made up of nylon laminated polyethylene of thickness 100 micron with a capacity of $200 \mathrm{~g}$ each and of size $30.0 \times 12.0 \mathrm{~cm}$. Each pack had a weight ranges from $150-200 \mathrm{~g}$.

The vacuum packed samples with or without treatment were coded as untreated vacuum packed steaks (A), $0.5 \%$ sodium benzoate treated vacuum packed steaks (B), $1.0 \%$ sodium benzoate treated vacuum packed steaks (C), $1.5 \%$ sodium benzoate treated vacuum packed steaks (D) and 2.0\% sodium benzoate treated vacuum packed steaks (E) respectively. Vacuum packed catla fish steaks were stored in an insulated thermocol box with crushed ice (1:1). Insulated fish box was kept at room temperature. Re-icing was done every day after proper draining of ice melt water to supplement the loss of ice due to melting. Storage studies were conducted for a period of 27 days. All the samples were analyzed at intervals of 3 days for sensory, biochemical and microbiological characteristics.

Sensory evaluation was carried out by trained panelist using 9 point hedonic scale (ISI, 1975). The scores given by the panelists for each of the attributes were pooled and the average scores are presented.
Biochemical changes viz. $\mathrm{pH}$, peroxide value (PV) and salt soluble nitrogen (SSN) were determined as per A0AC (2005), also total volatile base nitrogen (TVB-N) was determined by the procedure given by Beatty and Gibbons (1937). Total plate count (TPC), Escherichia coli, Staphylcoccus aureus and Salmonella as per USFDA (2001). Recorded data were analysed to test significant difference by applying analysis of variances (ANOVA) tool available in MS-Excel 2007 and Student-NewmanKeuls (SNK) test. The significant differences were tested by $5 \%$ level of significances and are mentioned as $\mathrm{p}<0.05$ for significances difference (Zar, 2004).

\section{RESULTS AND DISCUSSION}

The catla fish used for study had a total length ranges from 35 to $45 \mathrm{~cm}$ and total weight ranges from 1.2 to $1.5 \mathrm{~kg}$. The initial quality of raw material i.e. fresh catla fish is given in Table 1. The moisture, crude protein, fat and ash contents were 79.24, 18.59, 1.23 and $0.94 \%$ respectively (Table 2 ). The results for proximate composition are similar to that reported by Bhosale (2002) and Pawar et al. (2013) with a little difference. Gopakumar (2002) reported the moisture, crude protein, fat and ash contents in catla fish as 76.30, 19.60, 1.30 and $0.90 \%$ respectively. The variation in the chemical composition of sardines is closely related to nutrition, living area, fish size, catching season, seasonal and sexual variations as well as other environmental conditions (Ozogul et al., 2004).

Catla fish steaks treated with 0.5, 1.0, 1.5 and 2.0 $\%$ of sodium benzoate for 5 minutes showed residue of sodium benzoate $0.0192,0.0376,0.0664$ and $0.0952 \%$ respectively in meat (Table 3 ). The residual sodium ben-

\begin{tabular}{|l|l|}
\hline \multicolumn{2}{|l|}{ Table 1: Quality of fresh catla fish muscle } \\
\hline Quality parameter & Catla fish muscle \\
\hline $\begin{array}{l}\text { A. Sensory score for overall } \\
\text { acceptability (9 point hedonic } \\
\text { scale) }\end{array}$ & $9.0 \pm 1.07$ \\
\hline B. Biochemical quality & \\
\hline pH & $5.56 \pm 0.01$ \\
\hline TVB-N (mg/100g) & $7.15 \pm 0.01$ \\
\hline PV (meq of 02/ kg) & $2.37 \pm 0.03$ \\
\hline SSN (mg \% of total nitrogen) & $65.42 \pm 0.01$ \\
\hline C. Microbiological quality & \\
\hline Total plate count (cfu/g) & $5.39 \times 10^{2}$ \\
\hline Staphylococcus aureus & ND \\
\hline Escherichia coli & ND \\
\hline Salmonella & ND \\
\hline Note: ND = Not Detected & \\
\hline
\end{tabular}




\begin{tabular}{|c|c|}
\hline Composition (\%) & Catla fish muscle \\
\hline Moisture & 79.24 \\
\hline Crude protein & 18.59 \\
\hline Fat & 1.23 \\
\hline Ash & 0.94 \\
\hline
\end{tabular}

Table 3: Residue of sodium benzoate in treated catla fish muscle

\begin{tabular}{|l|l|}
\hline Treatment $(w / v)$ & $\begin{array}{l}\text { Residue after } 5 \text { min dip } \\
\text { treatment }\end{array}$ \\
\hline $0.5 \%$ & $0.0192 \%$ \\
\hline $1.0 \%$ & $0.0376 \%$ \\
\hline $1.5 \%$ & $0.0664 \%$ \\
\hline $2.0 \%$ & $0.0952 \%$ \\
\hline
\end{tabular}

zoate levels after 5 minute dip treatment did not exceed the acceptable limit of $0.1 \%$ for all treated steaks.

\section{SENSORY CHANGES}

During the chilled storage studies of 27 days, the overall acceptability score for all samples showed declining trend. Sample A showed acceptability score from 9.0 to 4.6 at the end of 18 days, while B, C, D and E showed acceptability score from 9.0 to $4.0,9.0$ to $4.1,9.0$ to 4.2 and 9.0 to 4.3 respectively at the end of 27 days (Fig. 1). The result of the present study is supported by Mohan et al. (2009) for overall acceptability of seer fish steaks packed with 02 scavenger during chilled storage. Jeyasekaran et al. (2004) also reported declining trend for overall acceptability scores of vacuum packed tuna
(Euthynnus affinis) chunks stored at refrigerated temperature. The results of ANOVA test for overall acceptability scores revealed that, there was no significant difference $(p>0.05)$ between them.

\section{BIOCHEMICAL CHANGES}

\section{Chnages in $\mathrm{pH}$}

The $\mathrm{pH}$ values for all samples of chilled stored catla fish steaks showed increasing trend from 5.56 to 6.37 in A, 5.55 to 6.35 in B, 5.55 to 6.32 in C, 5.55 to 6.30 in D and 5.55 to 6.27 in $\mathrm{E}$ at the end of 27 day (Fig. 2). On the same line, slight increase in $\mathrm{pH}$ (from 6.28 to 6.62) of mackerel (Rastrelliger kanagurta) stored with antimicrobials treated ice (prepared by adding mixture of sodium benzoate, Butylated Hydroxy Anisole; BHA and fumaric in the ratio 90:9:1 to the water at the concentration of 500 ppm) was reported by Chandra (2006).

Juvekar (2007) also reported rising trend in $\mathrm{pH}$ (from 6.38 to 7.08 ) of vacuum packed black king fish mackerel (Rachycentron canadus) flesh stored at $5 \pm 1^{\circ} \mathrm{C}$. The increase in $\mathrm{pH}$ may be attributed to the production of volatile base compounds and alkaline compounds such as ammonia by spoilage bacteria (Cann et al., 1983). The results of ANOVA test for $\mathrm{pH}$ revealed that, there was no significant difference $(p>0.05)$ between them.

\section{CHANGES IN TOTAL VOLATILE BASE NITROGEN (TVB-N)}

The TVB-N (mg/100g) content for all samples of chilled stored catla fish steaks showed increasing trend from 7.15 to 36.18 in $\mathrm{A}, 7.13$ to 33.51 in $\mathrm{B}, 7.13$ to 33.35 in C, 7.12 to 33.32 in $\mathrm{D}$ and 7.12 to 15.93 in $\mathrm{E}$ at the

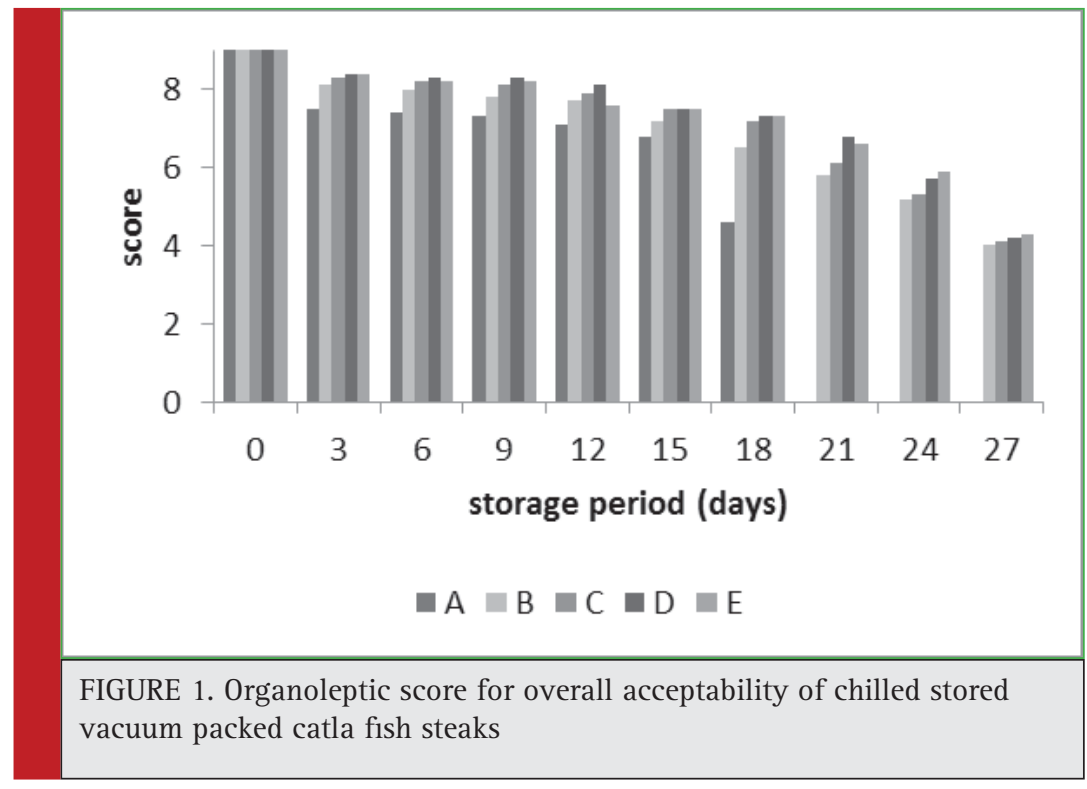




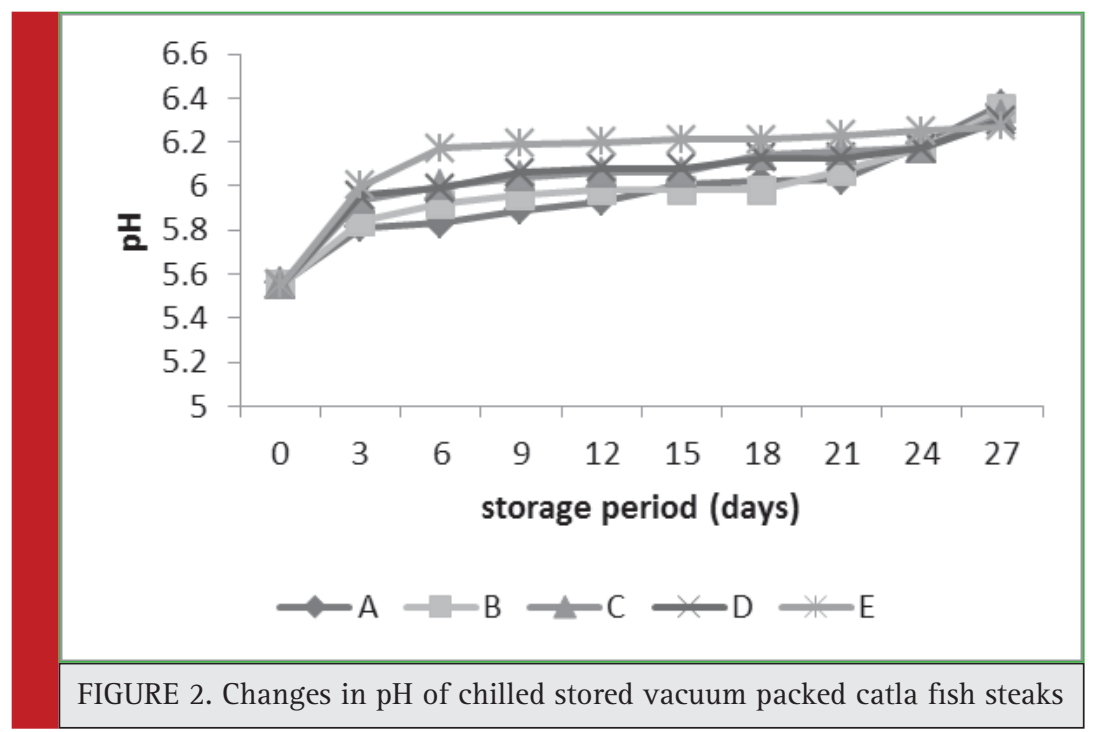

end of 27 day (Fig. 3). The TVB-N values of all samples were within the acceptable limit during chilled storage period. The similar results for TVB-N content (from 9.80 to $29.40 \mathrm{mg} / 100 \mathrm{~g}$ ) were recorded by Juvekar (2007) for vacuum packed black king fish mackerel (Rachycentron canadus) flesh stored at low temperature. On the same line, Ozogul et al. (2004) reported increasing trend of TVB-N (from $5.0 \mathrm{mg} / 100 \mathrm{~g}$ to $19.0 \mathrm{mg} / 100 \mathrm{~g}$ ) during chilled storage of vacuum packed sardines (Sardina pilchardus), whereas Karim et al. (2011) reported increase in TVB-N (from 22.40 to $68.32 \mathrm{mg} / 100 \mathrm{~g}$ ) during ice storage of herring (Clupea harengus).

The results of ANOVA test for TVB-N revealed that, there was significant difference $(\mathrm{p}<0.05)$ between them. Further results of Student-Newman-Keuls (SNK) test indicated that, sample E was significantly superior to other samples $(\mathrm{p}<0.05)$. Fraser and Sumar (1998) indicated that bacterial catabolism of amino acids in fish muscle results in the accumulation of ammonia and other volatile bases. Therefore, in the present study it can be concluded that combined effect of vacuum packaging and sodium benzoate inhibited the growth of microorganisms, which causes the slight increase in TVB-N value of sodium benzoate treated vacuum packed catla fish steaks.

\section{CHANGES IN PEROXIDE VALUE (PV)}

The peroxide value (meq of $02 / \mathrm{kg}$ ) for all samples of chilled stored catla fish steaks showed increasing trend from 2.37 to 9.75 in A, 2.36 to 6.25 in B, 2.36 to 5.25 in

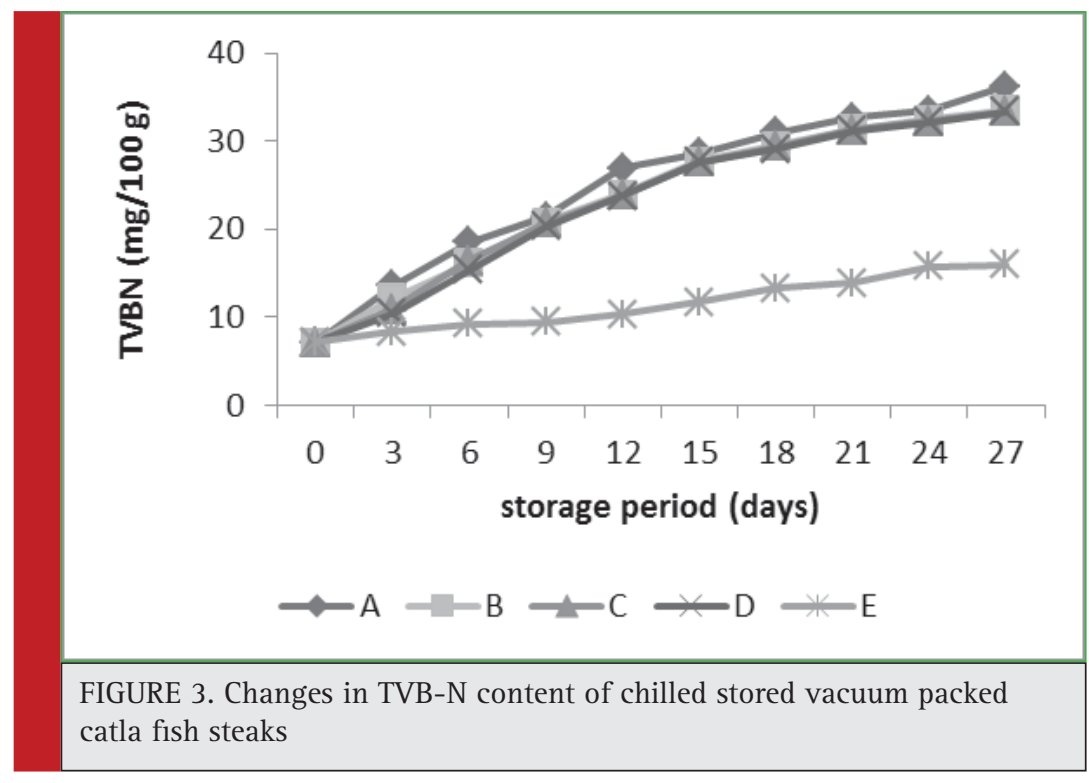




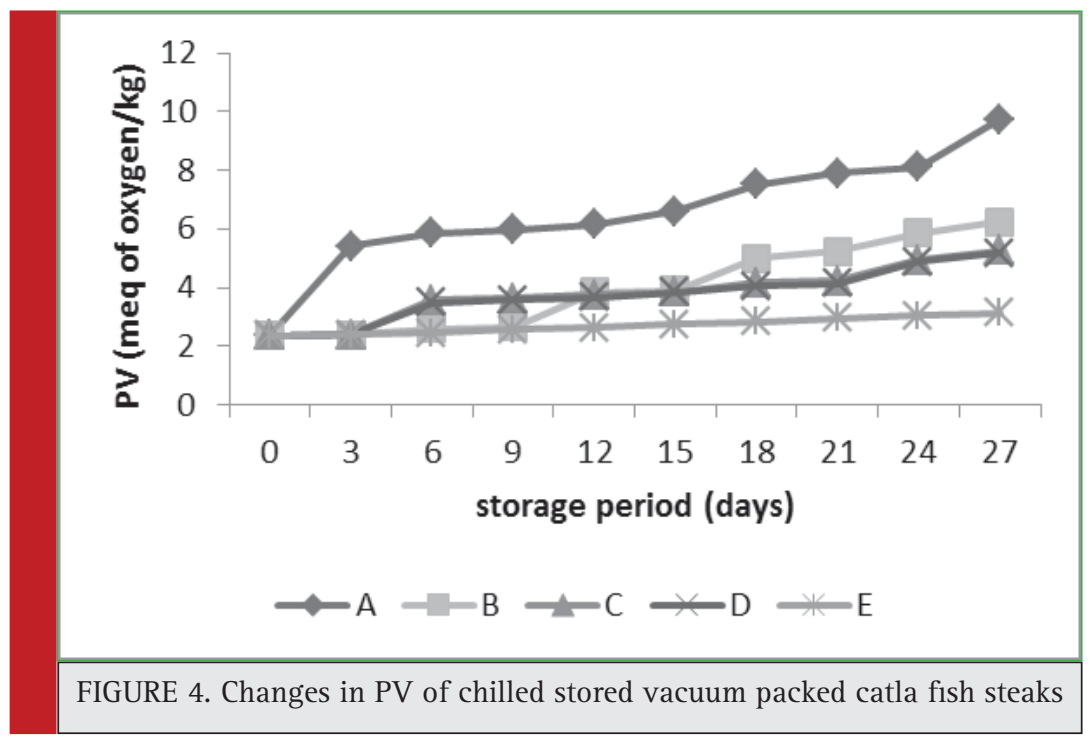

C, 2.35 to 5.18 in D and 2.35 to 3.12 in $\mathrm{E}$ at the end of 27 day (Fig. 4). On the same line, increase in PV (from 4.77 to 17.49 meq of $\mathrm{O}_{2} / \mathrm{kg}$ ) of mackerel (Rastrelliger kanagurta) stored with antimicrobials treated ice (prepared by adding mixture of sodium benzoate, Butylated Hydroxy Anisole; BHA and fumaric in the ratio 90:9:1 to the water at the concentration of $500 \mathrm{ppm}$ ) was reported by Chandra (2006). Phadke (2009) reported increasing trend (from 0.10 to $3.16 \mathrm{meq}$ of $02 / \mathrm{kg}$ ) in PV values of ice stored seer fish (S. guttatus) fillets.

The results of ANOVA test for peroxide value revealed that, there was significant difference $(p<0.05)$ between them. Further results of Student-Newman-Keuls (SNK) test indicated that, B, C, D and E samples were significantly different from sample A $(p<0.05)$, but signifi- cant difference was not observed between B, C, D and E samples. The PV values of of all samples were within the acceptable limit during chilled storage. The vacuum packed samples showed slower rate of increase in PV. It may be attributed to the vacuum packaging which offers an excellent protection against oxidative rancidity by the effective removal of oxygen in the packs (Ray, 2004).

\section{CHANGES IN SALT SOLUBLE NITROGEN (SSN)}

Salt soluble nitrogen (mg \% of total nitrogen) content for all samples of chilled stored catla fish steaks showed decreasing trend from 65.42 to 29.24 in A, 65.44 to 35.94 in B, 65.44 to 36.36 in C, 65.42 to 36.45 in D and 65.42 to 56.48 in $\mathrm{E}$ at the end of 27 day (Fig. 5).

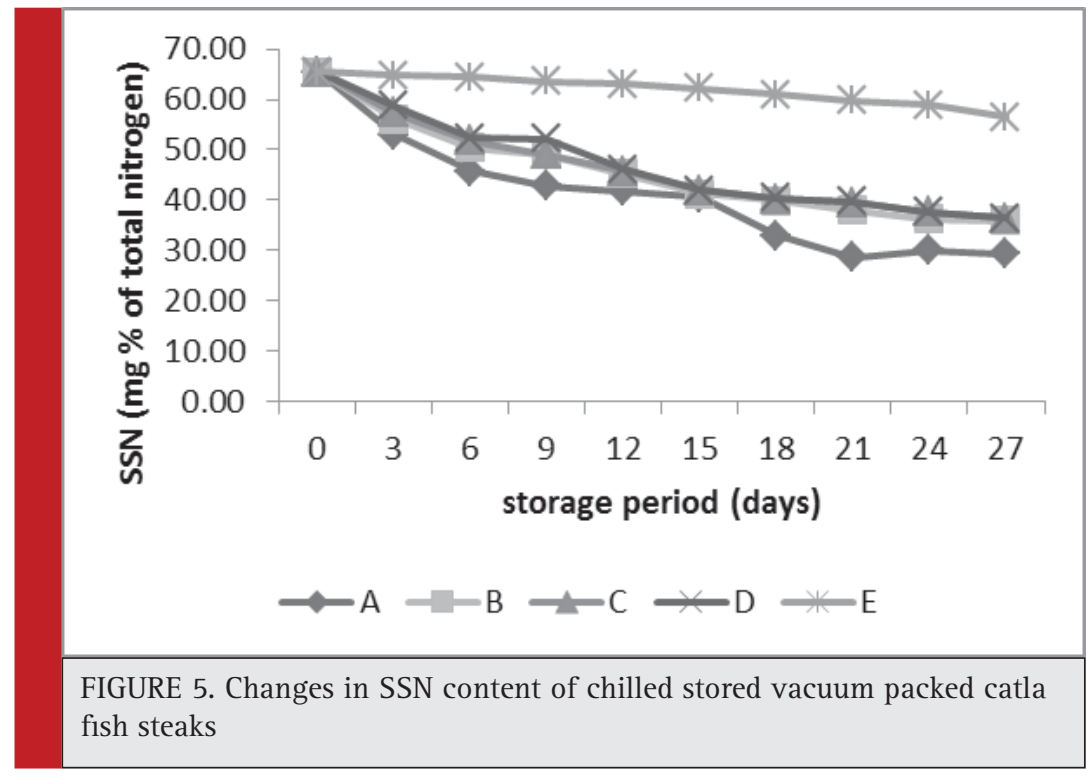




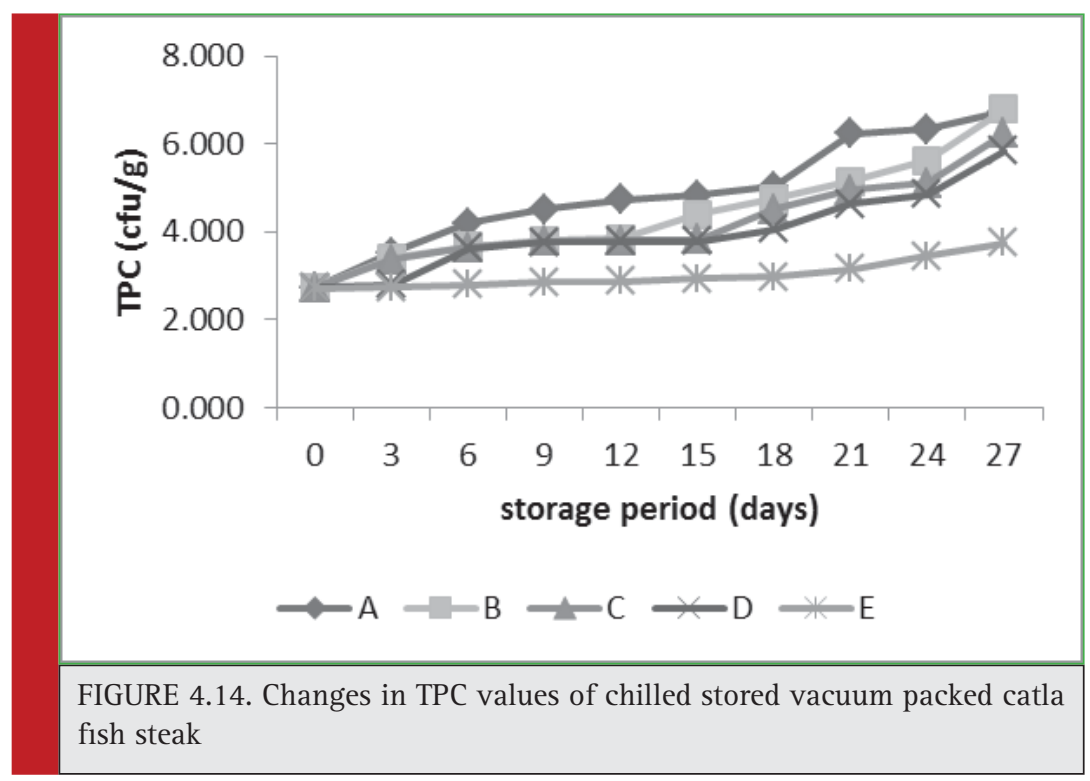

The results of ANOVA test for salt soluble nitrogen revealed that, there was significant difference $(p<0.05)$ between them. Further results of Student-NewmanKeuls (SNK) test indicated that, sample E was significantly superior to other samples $(p<0.05)$. Dunn and Rustad (2008) reported declined in salt soluble proteins in superchilled vacuum packed Atlantic salmon (Salmo salar) fillets during storage period. The decrease in SSN may be attributed to the protein denaturation in fish muscle (Dunn and Rustad, 2008).

\section{MICROBIOLOGICAL CHANGES}

Total plate count (cfu/g) for all samples of chilled stored catla fish steaks showed increasing trend from $5.38 \times 10^{2}$ to $6.31 \times 10^{6}$ in $\mathrm{A}, 5.37 \times 10^{2}$ to $6.03 \times 10^{6}$ in $\mathrm{B}, 5.35 \mathrm{x}$ $10^{2}$ to $1.74 \times 10^{6}$ in C, $5.34 \times 10^{2}$ to $7.08 \times 10^{5}$ in D and $5.32 \times 10^{2}$ to $5.62 \times 10^{3} \mathrm{in} \mathrm{E}$ at the end of 27 day (Fig. 6). Results of the present study are supported by reports on changes in TPC (from $1.0 \times 10^{4}$ to $1.0 \times 10^{6}$ ) of vacuum packed sardines (Sardina pilcharus) stored at $4^{\circ} \mathrm{C}$ (Ozogul et al., 2004). Manju et al. (2007) also noted increase in TPC (from $8.71 \times 10^{4}$ to $1.0 \times 10^{7}$ ) of chilled stored vacuum packed pearlspot (Etroplus suratensis). Juvekar (2007) reported increased trend of TPC (from $1.10 \times 10^{3}$ to $1.96 \times 10^{5}$ ) vacuum packed black king fish mackerel (Rachycentron canadus) flesh stored at low temperature.

The results of ANOVA test for total plate count revealed that, there was significant difference $(p<0.05)$ between them. Further results of Student-NewmanKeuls (SNK) test indicated that, D and E samples were significantly different from other samples $(p<0.05)$, but significant difference was not observed between $\mathrm{D}$ and E samples.
In the present study, vacuum packed sample with $2.0 \%$ sodium benzoate showed slower rate of increase in TPC as compared to other samples. It may be attributed to vacuum packaging which decreases the growth of aerobic spoilage microorganisms (Ray, 2004) and higher concentration of sodium benzoate which is having antimicrobial properties against bacteria, moulds and yeast (Omojowo et al., 2010).

The S. aureus, E. coli and Salmonella were not detected during the entire period of chilled storage in all samples of catla fish steaks. Similar results were reported by Rathod et al. (2014) in fish cutlet made from Pangasius fish (Pangasianodon hypophthalmus), during storage in refrigerated display unit $\left(-15\right.$ to $\left.-18{ }^{\circ} \mathrm{C}\right)$.

\section{CONCLUSION}

The results of present study revealed that vacuum packaging alone, without treatment, would not be of much effective under the reported experimental conditions. The results of the present study, clearly suggest that a combination of vacuum packaging, sodium benzoate and storage at chilled temperature could be used to prolong the shelf life of catla.

\section{ACKNOWLEDGEMENTS}

The authors are thankful to University authorities of Dr. B. S. Kokan Krishi Vidyapeeth, Dapoli, Associate Dean, College of Fisheries, Ratnagiri and National Agricultural Innovative Project (NAIP) project members for their encouragement and providing necessary facilities for the present work. 


\section{REFERENCES}

AOAC, (2005) Official methods of analysis of the Association of Official Analytical Chemists International, 18th edition, In: Horwitz, W. (Ed.), Association of Official Analytical Chemists, Washington (D. C.), 35: 2-36.

Beatty S. A. and Gibbons N. E. (1937) The measurement of spoilage in fish. J. Biol. Bd. Can., 3: 77-81.

Bhosale B. P. (2002) Studies on Frozen Storage Characteristics of a Freshwater Fish Catla catla (Bloch). M.F.Sc. Thesis submitted to Dr. Balasaheb Sawant Konkan Krishi Vidyapeeth, Dapoli, Maharashtra, pp. 1-116.

Cann D. L., Smith G. L. and Houston N. G. (1983) Further studies on marine fish stored under modified atmosphere packaging. Aberdeen: Ministry of Agriculture Fisheries and Food, Torry Research Station, Scotland. pp: 1-322.

CFR (2011) Food and Drugs, In: Code of Federal Regulations. Published by the Office of the Federal Register National Archives and Records Administration as a Special Edition of the Federal Register, Washington, DC. pp.:564-565.

Chandra K. (2006) Effect of antimicrobial ice on the quality and shelf life of Indian mackerel (Rastrelliger kanagurta). M.F.Sc. Thesis submitted to Dr. Balasaheb Sawant Konkan Krishi Vidyapeeth, Dapoli, Maharashtra, pp. 1-69.

Duun A. S. and Rustad T. (2008) Quality of superchilled vacuum packed Atlantic salmon (Salmo salar) fillets stored at -1.4 and $-3.6^{\circ} \mathrm{C}$. Food Chemistry, 106: 122-131.

Fraser, O. P., \& Sumar, S. (1998). Compositional changes and spoilage in fish (part II) microbiological induced deterioration. Nutrition and Food Sci., 6: 325-329.

Gopakumar K. (2002) Post-mortem changes in fish and quality assessment. In: Texbook of fish processing technology, Indian council of Agriculture Research, New Delhi, pp. 31-37.

ISI (1975) Guide for sensory evaluation of foods, Part III, Statistical Analysis of Data, Indian Standard Institute, (Part III), IS: 6273.

Jeyasekaran G., Maheswari K., Shakila R. J., Ganesan P. and Akshmanan R. L. (2004)

Bacterial quality of vacuum packed tuna (Euthynnus affinis) chunks stored under abused refrigerated temperatures. Asian Fish. Sci., 17: 217-227.

Juvekar P. (2007) Effect of vacuum packaging on the shelf life of black king fish

(Rachycentron canadus) flesh stored at low temperature. M.F.Sc. Thesis to Dr. Balasaheb Sawant Konkan Krishi Vidyapeeth, Dapoli, Maharashtra, pp. 1-82.

Karim N. U., Kennedy T., Linton M., Watson S., Gault N. and Margaret F. Patterson (2011)
Effect of high pressure processing on the quality of herring (Clupea harengus) and haddock (Melanogrammus aeglefinus) stored on ice. Food Control., 22: 476-484.

Mohan C. O., Ravishankar C. N., Gopal Srinivasa T. K., Kumar A. K. and Lalitha K. V. (2009) Biogenic Amines Formation in Seer Fish (Scombermorus commerson) Steaks Packed with 02 Scavenger during Chilled Storage. Food Research Int., 42: 411-416.

Manju S., Jose L., Srinivasa Gopal T. K., Ravishankar C. N. and Lalitha K. V. (2007) Effects of sodium acetate dip treatment and vacuum-packaging on chemical, microbiological, textural and sensory changes of Pearlspot (Etroplus suratensis) during chill storage. Food Chemistry, 102: 27-35.

Omojowo, Funso Samuel and Raji Aminu (2010) Assessment of the use of sodium benzoate on the safety and shelf-life of smoked Tilapia. New York Sci. J., 3 (6): 48-54.

Ozogul F., Polat A. and Ozogul Y. (2004) The effects of modified atmosphere packaging and vacuum packaging on chemical, sensory and microbiological changes of sardines (Sardina pilchardus). Food Chemistry, 85: 49-57.

Pagarkar, A. U., Kedar, J. G., Shingare, P. E. and Sawant, N. H. (2015) Seafood Industries: Modified Atmospheric Packaging, Journal of FISHCOOPS, 27 (3), 3-8,10-11.

Pawar P. (2013) Preparation of battered and breaded product from fresh water fish catla (Catla catla). M.F.Sc. Thesis submitted to Dr. Balasaheb Sawant Konkan Krishi Vidyapeeth, Dapoli, Maharashtra, pp. 1-93.

Phadke G. G. (2009) Effect of protein dispersion coating on chilled and frozen stored seer fish fillets. M.F.Sc. Thesis submitted to Dr. Balasaheb Sawant Konkan Krishi Vidyapeeth, Dapoli, Maharashtra, pp. 1-130.

Rathod, N., Pagarkar, A., Phadke,G., Pujari, K. H. , and Chandra, M. V. . (2014) Chemical, microbial and sensory changes of fish cutlet, made from Pangasius fish (Pangasianodon hypophthalmus), during storage in refrigerated display unit ( -15 to -18 0C). Ecol. Env. and Cons., 20 (3): 137-142.

Ray B. (2004) Fundamental Food Microbiology, Third edition; CRC Press LLC, Boca Raton, Florida, pp. 290-304.

Sara P. L., Takehiko K., Norio I. and Haruo S. (1994) Sardine immersed storage at $15^{\circ} \mathrm{C}$ in brine containing sodium benzoate. Bull. Fac. Fish. Hokkaido Univ., 45 (1): 19-25.

Shalima V. S. (1997) Biochemical changes in silver carp (Hypothalichthys molitrix) steaks during frozen storage at $-20^{\circ} \mathrm{C}$. M. F. Sc. Thesis submitted to Central Institute of Fisheries Education, Mumbai, pp. 52-58.

USFDA (2001) U.S. Food and drug Administration, Bacteriological Analysis Manual. http: www.usfda.com

Zar J. H. (2004) Multiple comparisons. In: Biostatistical analysis, Pearson Education, Pvt. Ltd. Delhi, pp. 208-230. 